\title{
MATEUSZ BARŁÓG
}

Uniwersytet Jagielloński, Instytut Psychologii

\section{RODZINY ZASTĘPCZE W POSTAWACH I OPINIACH MŁODYCH DOROSŁYCH}

Streszczenie: W artykule przedstawiono badanie przeprowadzone wśród młodych dorosłych w wieku 19-35 lat $(N=67)$. Celem stało się określenie związku informacji poprzedzającej zawartej w instrukcji badania z postawą względem rodzinnej pieczy zastępczej. W tym celu jednej grupie $(n=35)$ przekazano informację poprzedzającą o negatywnych zachowaniach wychowanków, a drugiej grupie informację pozytywną o możliwościach rozwoju $(n=32)$. Analizy statystyczne wskazują na brak związku pomiędzy rodzajem instrukcji a postawą badanych. Analizowano także związek postawy z ogólnym poziomem wiedzy o rodzicielstwie zastępczym. W tym przypadku wynik również okazał się nieistotny statystycznie. Wyniki zdają się natomiast wskazywać, że może istnieć związek badanej wiedzy i postawy z wiekiem badanych. Ponadto kobiety w porównaniu do mężczyzn cechują się zarówno bardziej pozytywną postawą względem pieczy zastępczej, jak i wyższym ogólnym poziomem wiedzy o rodzinach zastępczych. Dane wskazują także na ogólną dość wysoką wiedzę młodych dorosłych o systemie pieczy zastępczej w Polsce oraz na pozytywny stosunek do pomocy dzieciom i rodzinom zastępczym. W dyskusji omówiono możliwe implikacje praktyczne dla dalszych badań i profilaktyki.

Slowa kluczowe: piecza zastępcza, rodziny zastępcze, stereotypy, postawy.

\section{WPROWADZENIE}

Piecza zastępcza z definicji oznacza sprawowanie tymczasowej opieki nad dzieckiem, które z różnych względów nie może przebywać pod opieką rodziców biologicznych. Celem jest jak najszybsze wyjaśnienie sytuacji dziecka - dążenie do reintegracji rodziny lub umożliwienie adopcji (Andrzejewski, 2012; Giertuga-Miłek, 2006; Ustawa o wspieraniu rodziny i systemie pieczy zastępczej, 2011).

W systemie pieczy zastępczej można wyróżnić instytucjonalną oraz rodzinną pieczę zastęppzą. Formę instytucjonalną definiuje kilka typów placówek, natomiast rodzinną - rodziny zastępcze (spokrewnione, niezawodowe i zawodowe), a także rodzinne domy dziecka (Ustawa o wspieraniu rodziny i systemie pieczy zastępczej, 2011; Walęcka-Matyja, 2015). Na koniec 2018 r. w pieczy zastępczej przebywało prawie 72 tys. dzieci, a w samych rodzinach zastępczych ok. 55 tys. dzieci, jest to zatem ważny temat społeczny (Główny Urząd Statystyczny - Piecza zastępcza w 2018 r.).

Adres do korespondencji: m4teuszbarlog@gmail.com, ORCID: https://orcid.org/00000002-3966-159X. 
Analizy badawcze i statystyki wskazują, że dzieci z pieczy zastępczej sprawiają trudności opiekuńczo-wychowawcze, mają problemy w szkole czy wśród rówieśników, dlatego w literaturze przedmiotu podkreśla się potrzebę pracy nad rozwojem wychowanków (Kaszyński, Ornacka, 2018; Piekacz, 2015). Ponadto trudne doświadczenia mogą powodować problemy w funkcjonowaniu wychowanków, zarówno w okresie dorastania, jak i już w dorosłości. Często sytuacja dziecka może być potęgowana przez całkowitą zmianę trybu życia. Nowe środowisko zastępcze może zasadniczo różnić się od rodziny pochodzenia w zakresie zasad, wartości czy tradycji (Bruskas, 2008; Lewko, 2011; Kałucka, 2011; Ruszkowska, 2013; Walęcka-Matyja, 2015).

Opisywane trudności mogą być genezą do tworzenia się stereotypów. Badania z 2018 r. wskazują, że dzieci przebywające w instytucjonalnej pieczy zastępczej (domach dziecka) mogą być objęte stereotypem - niestety także wśród nauczycieli (Gamian-Wilk, Madeja-Bień, Domagała-Jędrzejewska, 2018). Jest to o tyle istotne, że dzieci pochodzące z rodzin problemowych mogą wymagać szczególnego wsparcia w najbliższym otoczeniu społecznym, chociażby w zakresie rozpoznania trudności i rozpoczęcia odpowiednich działań. Gdy dziecko nie odnajduje bezpieczeństwa w domu, poszukuje go właśnie wśród otoczenia społecznego. Stereotypy mogą natomiast prowadzić do zjawiska wykluczenia (Denzel, MacDonald, 2014; Madeja-Bień, Gamian-Wilk, 2017; Rogers, 2016; Sokołowska, 2012).

Pełne zrozumienie postaw otoczenia środowiskowego względem rodzin z trudnościami opiekuńczo-wychowawczymi wydaje się zatem ważne w perspektywie pracy pomocowej. Podstawą takich przypuszczeń jest chociażby teoria ekologiczna autorstwa Uriego Bronfenbrennera (1979). Autor wskazuje na interakcję czynników indywidualnych i środowiskowych dla prawidłowego rozwoju, przedstawiając znaczenie bliższego, ale i dalszego otoczenia społecznego. Współcześnie teoria ta jest jedną z podstaw teoretycznych do pracy z młodzieżą i jej rozwoju (Domagała-Zyśk, Knopik, Oszwa, 2017; Ettekal, Mahoney, 2017). Wydaje się także istotna w perspektywie poruszanego tematu, ponieważ opinie i postawy panujące w otoczeniu społecznym mogą kształtować psychospołeczne funkcjonowanie wychowanków. Ponadto obiektem stereotypu może być nie tylko główny jego podmiot, lecz także osoby z najbliższego otoczenia (Barłóg, Stradomska, 2015). Opinie i wsparcie społeczne mogą być zatem szczególnie ważne dla rodziców zastępczych, których zadania są niezwykle złożone (Weigl, 2011). Proces wychowawczy jest bowiem jednym z kluczowych determinantów dorosłej aktywności wychowanków pieczy zastępczej. To umiejętności i kompetencje rodziców zastępczych pośredniczą w interakcjach z wchodzącymi do rodziny dziećmi (Joachimowska, 2008; Walęcka-Matyja, 2015).

Reasumując, należy zdiagnozować postawy (i ich korelaty) wobec dzieci przebywających w pieczy zastępczej, aby w przyszłości móc w lepszym stopniu organizować działania pomocowe - zarówno wobec głównych zainteresowanych, jak i rozwijać działania profilaktyczne w szerszym kontekście społecznym.

\section{PROBLEM}

Stereotyp jest wyjątkową formą postawy, ponieważ charakteryzuje się uproszczonym komponentem poznawczym, tzn. podmiot posiada małą wiedzę na temat ocenianej jednostki lub przedmiotu. Stereotypy mają wydźwięk kulturowy, są zatem powielane przez poszczególnych uczestników życia społecznego, a przez to utrwalane w świa- 
domości jej członków. Stereotypy często mają negatywną wartość, prowadząc do niewłaściwych, krzywdzących zachowań względem jednostek i grup (Aronson, Wilson, Akert, 2006; Colman, 2009; Reber, Reber, 2008; Wojciszke, 2006).

Wydaje się zatem, że może istnieć związek poziomu wiedzy o pieczy zastępczej z postawą względem niej oraz związek informacji poprzedzającej na wyrażane przez badanych opinie. Większa wiedza powinna mieć przełożenie na niższy poziom stereotypowego myślenia, a przez to bardziej pozytywną postawę względem pieczy zastępczej. Ponadto założono, że uruchomienie stereotypowego myślenia na temat pieczy zastępczej poprzez zawarcie krótkiej informacji w instrukcji może wykazać związek z opiniami badanych, zgodnie z doniesieniami z innych badań psychologii społecznej (Aronson i in., 2006).

Następnie mając na uwadze teorię zadań rozwojowych Roberta Havighursta (Gurba, 2009); gdzie wśród celów młodych dorosłych zawiera się założenie rodziny i posiadanie potomstwa; założono, że wraz z wiekiem będzie rósł poziom pozytywnej postawy względem pomocy dzieciom. Wysunięto także hipotezę o istnieniu różnic płciowych, wynikających chociażby z roli społecznej i mającej związek z poznaniem i postrzeganiem społecznym (Aronson i in., 2006; Wojciszke, 2006, 2011).

$\mathrm{Na}$ tej podstawie postawiono główne pytania badawcze dotyczące problemów i celów badawczych, a brzmiały one następująco:

Czy istnieje związek pomiędzy poziomem wiedzy o pieczy zastępczej a postawą wobec niej?

Czy treść instrukcji - informacji poprzedzającej - różnicuje postawy wobec pieczy zastępczej?

Czy istnieje związek wieku z postawami wobec pieczy zastępczej?

Czy płeć różnicuje postawy wobec pieczy zastępczej?

Czy badani, którzy znają bezpośrednio rodziny zastępcze, mają o nich pozytywne zdanie?

\section{Założono cztery główne hipotezy:}

H1 - poziom wiedzy ogólnej na temat pieczy zastępczej ma związek z postawami względem niej. Wyższy poziom wiedzy koreluje dodatnio z postawą.

$\mathrm{H} 2$ - informacja poprzedzająca zawarta w instrukcji ankiety różnicuje poziom postawy względem pieczy zastępczej.

H3 - istnieje związek wieku z postawą wobec pieczy zastępczej. Wraz z wiekiem postawa wobec pieczy zastępczej jest bardziej pozytywna.

H4 - płeć różnicuje poziom postawy wobec pieczy zastępczej. Kobiety cechują się bardziej pozytywną postawą w porównaniu do mężczyzn.

Ponieważ badanie ma charakter eksploracyjny, nie postawiono hipotezy do piątego pytania badawczego.

\section{METODA}

Przebadano dwie grupy badawcze za pomocą dwóch autorskich ankiet: dotyczącej postaw względem pieczy zastępczej oraz badającej poziom ogólnej wiedzy o pieczy zastępczej. Grupy różniły się rodzajem informacji zawartej w instrukcji (pełna treść instrukcji w aneksie artykułu): 
- grupa pierwsza otrzymała instrukcję negatywną (podkreślono trudności opiekuńczo-wychowawcze sprawiane przez wychowanków);

- grupa druga otrzymała instrukcję pozytywną (podkreślono możliwości rozwoju wychowanków).

Ankieta do badania postawy wobec pieczy zastępczej składała się z 6 pytań na dyferencjale semantycznym 1-7, gdzie 1 oznacza zdecydowanie nie, a 7 - zdecydowanie tak. Trzy pytania miały charakter pytań odwróconych. Im wyższy wynik końcowy, tym bardziej pozytywna postawa względem dzieci w pieczy zastępczej. Maksymalny wynik to 42 punkty.

Natomiast ankieta badająca poziom wiedzy ogólnej na temat pieczy zastępczej składała się z dziesięciu pytań na skali odpowiedzi TAK - NIE. Odpowiedź prawidłowa była punktowana - im więcej punktów, tym większy poziom wiedzy dotyczącej pieczy zastępczej.

\section{UCZESTNICY BADANIA}

W wyniku doboru losowego przebadano 67 studentów, młodych dorosłych w wieku od 19. do 35. roku życia $(M=23,14 ; S D=3,74), 47$ kobiet $(70,1 \%$ grupy) oraz 20 mężczyzn (29,9\%). Wśród badanych osobiście wychowanka pieczy zastępczej znało 12 osób (17,9\% grupy) a 55 nie miało nigdy kontaktu z rodziną zastępczą/wychowankiem pieczy zastępczej (82,1\% grupy). Ze względu na rodzaj informacji poprzedzającej można wyróżnić dwie grupy badawcze: 35 osób badanych znalazło się w I grupie badawczej (z negatywną wersją instrukcji; 52,2\% grupy), 32 uczestników badania w grupie II (z pozytywną wersją instrukcji; 47,8\% grupy).

\section{WYNIKI}

W celu weryfikacji hipotezy pierwszej H1 przeprowadzono test korelacji rho-Spearmana, który wykazał brak związku pomiędzy poziomem wiedzy o pieczy zastępczej a postawą względem rodziny/wychowanków $\left(r_{s}=0,001 ; p=0,49\right)$.

Także analizy statystyczne weryfikujące hipotezę $\mathrm{H} 2$ prowadzą do wniosku, że rodzaj instrukcji (pozytywna bądź negatywna informacja o pieczy zastępczej) nie różnicuje postawy względem rodziny zastępczej/wychowanków (test Manna-Whitneya: $Z=-0,14 ; p=0,89)$. Instrukcja nie różnicuje także wyniku wiedzy ogólnej na temat rodzicielstwa zastępczego (test Manna-Whitneya: $Z=-0,88 ; p=0,38$ ).

TABELA 1

Średni wynik postawy względem pieczy zastępczej a rodzaj instrukcji

\begin{tabular}{lcccc}
\hline & \multicolumn{4}{c}{ Średni wynik postawy względem pieczy zastępczej } \\
\hline Rodzaj instrukcji & $n$ & $M$ & $S D$ & $p$ \\
\hline I (negatywna) & 35 & 33,09 & 4,20 & 0,89 \\
II (pozytywna) & 32 & 33,03 & 3,36 & \\
\hline
\end{tabular}

Źródło: opracowanie własne. 
TABELA 2

Średni wynik wiedzy o pieczy zastępczej a rodzaj instrukcji

\begin{tabular}{lcccc}
\hline & \multicolumn{4}{c}{ Średni wynik wiedzy o pieczy zastępczej } \\
\hline Rodzaj instrukcji & $n$ & $M$ & $S D$ & $p$ \\
\hline I (negatywna) & 35 & 5,57 & 1,70 & \multirow{2}{*}{0,38} \\
II (pozytywna) & 32 & 5,31 & 1,15 & \\
\hline
\end{tabular}

Źródło: opracowanie własne.

Analiza korelacji rho-Spearmana potwierdziła natomiast hipotezę trzecią H3. Istnieje pozytywny związek między wiekiem a wynikiem wiedzy ogólnej o pieczy zastępczej $\left(r_{s}=0,263 ; p=0,016\right)$ oraz na poziomie tendencji statystycznej między wiekiem a wynikiem w postawie względem pieczy zastępczej $\left(r_{s}=0,178 ; p=0,075\right)$. Siła obu opisywanych korelacji jest jednak słaba/niska.

TABELA 3

Poziom korelacji między wiekiem a badanymi zmiennymi

\begin{tabular}{lcc}
\hline \multicolumn{1}{c}{ Zmienna } & $r$ & $P$ \\
\hline wynik postawy wobec pieczy zastępczej & 0,178 & 0,075 \\
wynik wiedzy o pieczy zastępczej & 0,263 & 0,016 \\
\hline
\end{tabular}

Źródło: opracowanie własne.

Analiza istotności różnic pozwala także na pozytywną weryfikację hipotezy H4. Porównanie badanych kobiet i mężczyzn wykazuje różnice w średniej wyniku postawy względem pieczy zastępczej (test Manna-Whitneya $Z=-2,167 ; p=0,03$ ) oraz średniej wyniku wiedzy o pieczy zastępczej (test Manna-Whitneya $Z=-2,323 ; p=0,02$ ). Kobiety w obu przypadkach cechują się wyższą średnią.

TABELA 4

Średni wynik postawy względem pieczy zastępczej a pteć

\begin{tabular}{lcccc}
\hline & \multicolumn{5}{c}{ Średni wynik postawy względem pieczy zastępczej } \\
\hline \multicolumn{1}{c}{ Grupa } & $n$ & $M$ & $S D$ & $p$ \\
\hline Kobiety & 47 & 33,68 & 3,74 & 0,03 \\
Mężczyźni & 20 & 31,6 & 3,57 & \\
\hline
\end{tabular}

Źródło: opracowanie własne.

TABELA 5

Średni wynik wiedzy o pieczy zastępczej a pteć

\begin{tabular}{lcccc}
\hline & \multicolumn{4}{c}{ Średni wynik wiedzy o pieczy zastępczej } \\
\hline \multicolumn{1}{c}{ Grupa } & $n$ & $M$ & $S D$ & $p$ \\
\hline Kobiety & 47 & 5,7 & 1,23 & 0,02 \\
Mężczyźni & 20 & 4,85 & 1,79 & \\
\hline
\end{tabular}

Źródło: opracowanie własne. 
Dodatkowo wśród 67 badanych - 12 z nich miało bezpośrednią styczność z rodziną zastępczą/zna wychowanka pieczy zastępczej. Z tych 12 osób 10 ma pozytywne zdanie o tej konkretnej rodzinie, a 2 osoby zaznaczyły odpowiedź „trudno powiedzieć", żaden $\mathrm{z}$ badanych nie ma negatywnej opinii. Jest to różnica istotna statystycznie $\left(\chi 2_{(1, N=12)}=5,33 ; p=0,02\right)$, co wskazuje na pozytywne doświadczenia $\mathrm{w}$ kontakcie badanych z rodzinami zastępczymi.

TABELA 6

Opinia o znajomych wychowankach pieczy zastępczej

\begin{tabular}{ccccc}
\hline$N$ & $\begin{array}{c}\text { pozytywne } \\
\text { odczucia }\end{array}$ & $\begin{array}{c}\text { trudno } \\
\text { powiedzieć }\end{array}$ & Chi $^{2}$ & $p$ \\
\hline 12 & 10 & 2 & 5,33 & 0,02 \\
\hline
\end{tabular}

Źródło: opracowanie własne.

\section{DYSKUSJA}

Analizy badawcze pozwoliły pozytywnie zweryfikować dwie z czterech zakładanych hipotez badawczych - tj. te dotyczące związku wieku (hipoteza H3) i płci (hipoteza H4) z wynikiem postawy wobec pieczy zastępczej. Natomiast 2 hipotezy - dotyczące związku wiedzy z postawą (hipoteza $\mathrm{H} 1$ ) oraz rodzaju instrukcji (informacji poprzedzającej) z postawą (hipoteza H2) nie potwierdziły się. Badanie dostarcza zatem kilku interesujących wniosków oraz pytań badawczych na przyszłość.

Pozytywna weryfikacja hipotezy $\mathrm{H} 3$ pokazuje, że może istnieć związek pomiędzy wiekiem a wynikiem wiedzy ogólnej o rodzicielstwie zastępczym oraz pomiędzy wiekiem a wynikiem postawy względem pieczy zastępczej. Siła korelacji i poziom istotności statystycznej wskazują jednak na potrzebę eksploracji zagadnienia na większej próbie.

Ponadto płeć istotnie różnicuje średni wynik postawy i średni wynik wiedzy o pieczy zastępczej, co potwierdza hipotezę H4. Kobiety cechują się wyższym od mężczyzn wynikiem wiedzy o rodzicielstwie zastępczym oraz wyższym wynikiem w zakresie pozytywnej postawy względem pieczy zastępczej.

Potwierdzają się zatem podstawowe teorie dotyczące zadań rozwojowych oraz specyfiki młodej dorosłości, gdzie jednym z podstawowych wyzwań jest założenie rodziny i posiadanie dzieci (Bee, 2004; Gurba, 2009; Przetacznik-Gierowska, Tyszkowa, 2011). Być może istotnie wyższy wynik u kobiet jest związany z rolą społeczną, stereotypami płci i jej cech, co różnicuje postrzeganie rozmaitych aspektów rzeczywistości przez kobiety i mężczyzn (Aronson i in., 2006; Wojciszke, 2006, 2011). Badanie uzupełnia także doniesienia o znaczeniu inteligencji emocjonalnej i samooceny dla postrzegania problematyki pomocy społecznej i gotowości do pełnienia roli rodzica zastępczego lub adopcyjnego (Barłóg, Stradomska, 2017). Liczne badania pokazują zazwyczaj wyższy poziom inteligencji emocjonalnej u kobiet (Knopp, 2012).

Jednocześnie potwierdzenia nie znalazły dotychczasowe badania, wskazujące na znaczenie zdarzeń poprzedzających na uruchamianie stereotypów (Aronson i in., 2006).

Wyjaśnienie takiego wyniku może być rozmaite i wymaga dalszych badań. Przyczyną może być dość słaby przekaz informacji w postaci instrukcji kwestionariusza, pomimo pogrubienia czcionki. Z perspektywy metodologicznej warto zwrócić uwagę, czy badani w pełni skupiają się na treściach przekazywanych przez badacza w instrukcji. Wydaje się, że zmiana przekazu stereotypizującej treści z instrukcji na inne formy 
mogłaby korelować z zakładanym w hipotezie wynikiem. Ponieważ znaczenie w tym zakresie ma zarówno organizacja, jak i środek przekazu (Wojciszke, 2006), procesy poznawcze i emocjonalne (Doliński, 2000, 2005). Można także rozważyć inne klasyczne formy badania stereotypów, np. przymiotnikowe (Weigl, 2000).

Być może wynik pozostałby jednak ten sam, a przyczyny można upatrywać w teoriach postaw. Przy osobistych kwestiach, postawach, wartościach decydujemy sami, a zdanie innych nie jest już tak kluczowe. Postawa względem rodziny i dzieci jest jedną z najbardziej osobistych i być może na tyle trwałych, że krótkie informacje nie są w stanie mieć związku z percepcją badanych. Zarazem pomoc słabszym i potrzebującym jest jedną z podstawowych postaw wdrażanych kulturowo i być może ta ogólna tendencja pomocy innym jest wyrażana również przez bardziej szczegółową postawę (Wojciszke, 2006) - tzn. pomocy dzieciom w pieczy zastępczej. W celu weryfikacji przypuszczeń należałoby także wybrać metodę weryfikującą w inny sposób postawę niż w postaci deklaratywnej. Rozważania te mogą zatem stanowić przyczynek dalszych implikacji.

Badani młodzi dorośli mieli rzadki kontakt z wychowankami, zatem ich wiedza i opinie zazwyczaj nie były poparte doświadczeniami. W przypadku nauczycieli, którzy doświadczają licznych trudności w procesie edukacyjnym i mają kontakt z dziećmi $\mathrm{z}$ różnych środowisk - badania wykazały odmienne/ bardziej stereotypowe postrzeganie dzieci z domów dziecka (Gamian-Wilk i in., 2018).

Pozytywnym wnioskiem z badań jest dość wysoki wynik ogólnej wiedzy o pieczy zastępczej, chociaż widoczna jest potrzeba dalszej promocji rodzicielstwa zastępczego i wiedzy o nim. Respondenci mają pozytywną opinię o pieczy zastępczej i ideach pomocy społecznej. Ponadto z 12 osób, które znają wychowanków pieczy zastępczej, większość ma pozytywne relacje. Przełamuje to stereotyp, że dzieci wychowywane poza rodziną naturalną sprawiają wyłącznie trudności. Promowanie wiedzy dotyczącej rodzicielstwa zastępczego z pewnością jest ważne dla skuteczności działań pomocowych, kształtuje bowiem środowisko społeczne, w którym funkcjonuje rodzina zastępcza. Ma to znaczenie dla rozwoju wychowanków, dlatego w literaturze przedmiotu znajduje się potrzebę stałej promocji rodzicielstwa zastępczego (Błażejewska, 2014).

Ważnym jest także wzmacnianie zasobów indywidualnych, ponieważ mają one związek nie tylko z funkcjonowaniem jednostki w różnych sytuacjach, lecz także postrzeganiem rzeczywistości.

\section{BIBLIOGRAFIA}

Andrzejewski, M. (2012). Ewolucja pieczy zastępczej przez pryzmat nowych regulacji prawnych. Teologia i Moralność, 11, $105-125$.

Aronson, E., Wilson, T.D., Akert, R.M. (2006). Psychologia spoteczna. Serce i umyst. Poznań: Zysk i S-ka.

Barłóg, M., Stradomska, M. (2015). Percepcja osoby w związku romantycznym $\mathrm{z}$ wyznawcą islamu. Fides et ratio, 3(23), 118-128.

Barłóg, M., Stradomska, M. (2017). Zasoby indywidualne jednostki a współczesna problematyka płodności i prokreacji (cz. II). Samoocena i inteligencja emocjonalna jako indywidualne predykatory gotowości do tworzenia rodziny zastępczej, rodziny adopcyjnej oraz postawy względem pomocy społecznej. Fides et ratio, 3(29), 276-288.

Bee, H. (2004). Psychologia rozwoju cztowieka. Poznań: Zysk i S-ka.

Błażejewska, K. (2014). Bariery i szanse rodzicielstwa zastępczego. Rodzina zastępcza receptą na kryzys? Pogranicze. Studia Spoteczne, XXIV, 167-180. 
Bronfenbrenner, U. (1979). The ecology of Human development: Experiments by nature and design. Cambridge: Mass, Harvard University Press.

Bruskas, D. (2008). Children in Foster Care: A Vulnerable Population at Risk. Journal of Child and Adolescent Psychiatric Nursing, 21(2), 70-77.

Colman, A.M. (2009). Stownik psychologii. Warszawa: WN PWN.

Denzel, D., MacDonald, M.L. (2014). Stigma and foster care: An empirical investigation. Amherst: University of Massachusetts.

Doliński, D. (2000). Psychologia wptywu spotecznego. Wrocław: Ossolineum.

Doliński, D. (2005). Techniki wptywu spotecznego. Warszawa: Wydawnictwo Naukowe Scholar.

Domagała-Zyśk, E., Knopik, T., Oszwa, U. (2017). Diagnoza funkcjonalna rozwoju spoteczno-emocjonalnego uczniów $w$ wieku 9-13 lat. Warszawa: Ośrodek Rozwoju Edukacji.

Ettekal, A., Mahoney, J.L. (2017). Ecological systems theory. W: K. Peppler (red.), The $S A G E$ encyclopedia of out-of-school learning (s. 239-241). Publisher: SAGE.

Gamian-Wilk, M., Madeja-Bień, K., Domagała-Jędrzejewska, S. (2018). Różnice pomiędzy oceną zachowania dziecka wychowującego się w placówce opiekuńczo-wychowawczej jako instytucji pieczy zastępczej a dziecka wychowywanego w rodzinie. Teraźniejszość - Człowiek -Edukacja, t. 21, 4(84), 99-112.

Giertuga-Miłek, K. (2006). Adopcja i rodzina zastępcza jako forma rodzinnej opieki dla dzieci opuszczonych i porzuconych. Studia Lubuskie, 2, 83-95.

Główny Urząd Statystyczny - Piecza zastępcza w 2018 r.

Gurba, E. (2009). Wczesna dorosłość. W: B. Harwas-Napierała, J. Trempała (red.), Psychologia rozwoju cztowieka. Charakterystyka okresów rozwojowych cztowie$k a$ (s. 202-233). Warszawa: WN PWN.

Joachimowska, M. (2008). Rodzicielstwo zastępcze. Idea-problemy - analizy-kompetencje. Bydgoszcz: Wydawnictwo UKW.

Kałucka, R. (2011). Nowy dom, nowa rodzina - perspektywa relacji między dzieckiem a najbliższym otoczeniem w kon- tekście adaptacji w rodzinnym domu dziecka. W: L. Drozdowski, B. Weigl (red.), Rodzinne domy dziecka - opieka, wychowanie, terapia (s. 37-67). Warszawa: Fundacja Orlen-Dar serca.

Kaszyński, H., Ornacka, K. (2018). Rodzinna piecza - perspektywa klinicznej pracy socjalnej. W: M. Kordaczuk-Wąs, M. Wiktorowicz- Sosnowska (red.), Rodzina zastępcza. Pomiędzy prawem, teoria i praktyka (s. 23-39). Wrocław: Exante.

Knopp, K.A. (2012). Czy kobiety naprawdę są bardziej inteligentne emocjonalnie niż mężczyźni? O różnicach międzypłciowych w zakresie zdolności emocjonalnych. Fides et Ratio, 4(12), 95-112.

Lewko, G. (2011), Obraz kliniczny dziecka trafiającego do różnych form opieki zastępczej W: L. Drozdowski, B. Weigl (red.), Rodzinne domy dziecka - opieka, wychowanie, terapia (s. 67-90). Warszawa: Fundacja Orlen - Dar serca.

Madeja-Bień, K., Gamian-Wilk, M. (2017). Wybrane skutki wykluczenia społecznego. Teraźniejszość - Cztowiek - Edukacja, 20, 4(80), 45-58.

Przetacznik-Gierowska, M., Tyszkowa, M. (2011). Psychologia rozwoju cztowieka. Warszawa: WN PWN.

Piekacz, A. (2015). Dojrzałość społeczna wychowanków instytucjonalnej pieczy zastępczej w perspektywie psychologicznej. Zeszyty naukowe Politechniki Ślaskiej, Seria Organizacja i Zarządzanie, 85, 407-417.

Ruszkowska, M. (2013). Diagnoza rodzin zastępczych $w$ obliczu dylematów wspótczesności. Warszawa: Centrum Rozwoju Zasobów Ludzkich.

Reber, A.S., Reber, E. (2008). Stownik psychologii. Warszawa: Wydawnictwo Naukowe Scholar.

Rogers, J. (2016). 'Different' and 'devalued': Managing the stigma of foster-care with the benefit of peer support. The British Journal of Social Work, 47(4), 1078-1093.

Ustawa o wspieraniu rodziny i systemie pieczy zastępczej (2011).

Sokołowska, J. (2012). O potrzebie współpracy na rzecz dzieci ulicy w świetle badań biograficznych. W: M. Dębski, A. Kwaśnik, A. Wicka-Łangowska (red.), Fo- 
rum o bezdomności bez lęku (s. 51-66). Gdańsk: Polskie Forum na rzecz Wychodzenia z Bezdomności.

Walęcka-Matyja, K. (2015). Psychologiczne aspekty procesu wychowania dzieci w środowisku rodzin zastępczych. Kwartalnik Naukowy Fides et Ratio. Bliskie relacje interpersonalne, 3(23), 205-218.

Weigl, B. (2000). Stereotypy i uprzedzenia. W: Strelau, J. (red.) Psychologia: podręcznik akademicki (wyd. 1). Gdańsk: GWP.
Weigl, B. (2011). Osoby prowadzace rodzinny dom dziecka. Obciążenia i zasoby w pełnym cyklu życia. W: L. Drozdowski, B. Weigl (red.), Rodzinne domy dziecka - opieka, wychowanie, terapia (s. 21-28). Warszawa: Fundacja Orlen - Dar serca.

Wojciszke, B. (2006). Człowiek wśród ludzi. Zarys psychologii spotecznej. Warszawa: Wydawnictwo Naukowe Scholar.

Wojciszke, B. (2011). Psychologia spoteczna. Warszawa: Wydawnictwo Naukowe Scholar.

\section{ANEKS}

\section{Instrukcja nr 1}

Statystyki i analizy badawcze dotyczace rodzin zastępczych i dzieci w nich wychowywanych wskazuja, że pomimo zwiększającej się wiedzy i liczby badań, nadal jest wiele potrzeb-dzieci te sprawiaja trudności opiekuńczo-wychowawcze, w szkole czy domu, a problemy te obserwuje się także $w$ ich dorostym życiu...

\section{Instrukcja nr 2}

Statystyki i analizy dotyczące rodzin zastępczych i dzieci w nich wychowywanych wskazu$j a, \dot{z}$ e przy zwiększajacej się wiedzy dotyczacej wsparcia i przy odpowiednich dziataniach dzieci te moga funkcjonować na dobrym poziomie w szkole i domu oraz osiagnać sukces $w$ dorostym życiu...

\section{FAMILY FOSTER CARE IN THE ATTITUDES AND OPINIONS OF YOUNG ADULTS}

Abstract: This article presents a study conducted amongst young adults between the ages of $19-35(N=67)$. The aim was to determine the relationship between the about information about foster care families and the attitude of young adults towards them. For this purpose, one group $(n=35)$ was provided with information preceding the negative behavior of juveniles, and the other group received positive information about development opportunities $(n=32)$. Statistics indicate there is no relationship between the given information and the attitude of the respondents. The relationship between the attitude and general knowledge of young adults regarding foster parenthood was analyzed. In this case, the result also proved to be statistically insignificant. However, the results seem to indicate that there may be a relationship between the knowledge, attitude and age of the respondents. In addition, women had a more positive attitude towards foster care, and a wider knowledge about foster families compared to men. The data also indicate a fairly high level of knowledge of young adults about the foster care system in Poland. Respondents also have a positive attitude towards helping children and foster care families. The article discusses possible practical implications for further research and prevention.

Keywords: foster care, foster care families, stereotypes, attitudes. 